\title{
Rancang Bangun Sistem Rekomendasi Makanan Alternatif Berkalori Lebih Rendah Berbasis Konten Menggunakan Hierarchical Clustering
}

\author{
Dhienalight $^{1^{*}}$, Caecilia Citra Lestari ${ }^{2}$ \\ 1,2 Jurusan Teknik Informatika, Universitas Ciputra, Surabaya, Jawa Timur \\ Email: ${ }^{1 *}$ dhienalight@gmail.com, ${ }^{2}$ caecilia.citra@ciputra.ac.id.
}

(Naskah masuk: 15 Jun 2020, direvisi: 23 Sep 2020, diterima: 29 Sep 2020)

\begin{abstract}
Abstrak
Dengan banyaknya variasi makanan yang ada sekarang, masyarakat perlu menyadari bahwa perilaku menjaga pola makan yang baik merupakan suatu investasi penting untuk tubuh sehat. Pilihan untuk mengkonsumsi makanan alternatif adalah salah satu cara orang dapat makan apa yang diinginkan selagi menjaga jumlah kalori yang dikonsumsi. Akan tetapi, memilih makanan alternatif tersebut bukan merupakan hal mudah. Makanan pengganti harus sesuai dengan jumlah kalori yang dibutuhkan tubuh dan memiliki rasa makanan yang diminati. Dalam penelitian ini, penulis mengajukan rancang bangun sistem rekomendasi berbasis konten dengan hierarchical clustering yang dapat memberikan rekomendasi makanan alternatif berkalori lebih rendah dengan rasa serupa berdasarkan bahan makanan untuk membantu orang dalam menjaga konsumsi kalori mereka. Data makanan diambil dari basis data FatSecret karena mengandung banyak variasi makanan dan informasi jelas akan bahan dan kalori makanan. Sistem rekomendasi tersebut akan fokus pada data kalori dan bahan makanan serta data makanan pilihan pengguna. Dengan menggunakan machine learning library scikit-learn Python, data makanan yang ada akan dikelompokkan dengan hierarchical clustering untuk pembentukan kelompok makanan serupa lalu dilakukan filtering sehingga mendapatkan urutan rekomendasi yang sesuai. Hasil pengujian sistem rekomendasi melalui eksperimen terhadap 10 makanan yang telah dituliskan melalui survei dan dinilai oleh 32 responden menunjukkan bahwa sistem rekomendasi ini berhasil berdasarkan indeks penilaian keseluruhan rekomendasi sebesar 71,3\% yang mengindikasi hasil memuaskan oleh responden. Akan tetapi, akurasi masih perlu ditingkatkan karena urutan rekomendasi yang kurang sesuai kepuasan pengguna dengan saran penambahan faktor bentuk, kategori, dan bahan utama makanan.
\end{abstract}

Kata Kunci: sistem rekomendasi, content-based filtering, makanan alternatif, hierarchical clustering.

\section{Content-Based Recommender System For Alternative Food Containing Lower Calorie Values Using Hierarchical Clustering}

\begin{abstract}
Due to a large variety of food available for consumption, people need to realise that maintaining a healthy diet is a good investment for their bodies. Choosing alternative food is one of the ways people can eat what suits their taste while keeping a watch on their calorie intake. On the other hand, identifying preferred alternative food itself is a challenge because of conflicting nutritional needs versus wanting for good food. In this paper, the author proposed a content-based filtering recommender system that can gives out lower calorie foods with similar tastes based on its ingredients to help people watch their calorie intakes. The system focuses on food calories, its ingredients, and the user's food choices. Using Python machine learning library scikit-learn, the food data will be categorized through hierarchical clustering to get a group of similar food items and then filtered to achive a proper order of recommendation. The experimentation result of 10 food choices written in a survey and tested by 32 respondents showed that the recommender system succeeded based on the overall assessment index reaching 71,3\% which indicates a satisfactory responsed. However, the accuracy of the system needs to be improved because the given recommendation order data didn't suit the respondents' choices, with improvement centering on additional data as to the shape, category, and main ingredient of the food.
\end{abstract}

Keywords: recommender system, content-based filtering, alternative food, hierarchical clustering. 


\section{PENDAHULUAN}

Perkembangan ekonomi pada sebagian besar wilayah di dunia telah menyebabkan peningkatan pada jumlah makanan per kapita dan mempengaruhi pola makan masyarakat, yang mendorong munculnya wabah obesitas dan berat badan tidak ideal akibat asupan nutrisi tidak sesuai, serta penyakit-penyakit komplikasi seperti diabetes tipe 2, penyakit kardiovaskular, dan kanker [1]. Hal tersebut dapat dicegah dan diatasi dengan mengatur pola makan yang dimiliki, terutama jumlah kalori yang dikonsumsi tubuh. Berdasarkan data dari World Health Organization, Food and Agriculture Organization of the United Nations, United Nations University (WHO/FAO/UNU), setiap orang memiliki kebutuhan kalori yang berbeda-beda tergantung fisik tubuh, tingkat aktivitas, dan gaya hidup sehingga pola makan harus disesuaikan untuk mempertahankan kondisi tubuh yang baik [2]. Namun, dengan batasan-batasan yang ada, tidak semua dapat menerima perubahan dengan mudah sehingga muncul masalah akan pilihan makanan yang sesuai.

Salah satu cara yang memungkinkan orang untuk mengkonsumsi makanan yang diminati sekaligus menjaga kadar kalori mereka adalah dengan memilih makanan alternatif. Makanan alternatif yang dimaksud adalah makanan pengganti yang memiliki kandungan bahan baku sesuai dengan minat pengguna tetapi dengan jumlah kalori yang lebih rendah.

Dalam penelitian ini, penulis mengajukan solusi dalam bentuk aplikasi Android untuk membantu pengguna dengan memberi rekomendasi makanan alternatif berbasis konten yang sesuai. Data makanan yang ada berasal dari basis data FatSecret, dipilih karena mengandung banyak variasi makanan dengan informasi akan bahan makanan dan kalori makanan yang jelas. Aplikasi tersebut menerapkan algoritma agglomerative hierarchical clustering untuk membentuk kelompok item, berupa makanan yang menghasilkan topik hirarki, dimana topik akan diproses untuk menjadi aspek fitur dari item [3]. Setelah terbentuk kelompok, maka kelompok yang mengandung pilihan pengguna akan diambil untuk dilaksanakan content-based filtering sehingga mendapatkan urutan rekomendasi yang sesuai.

Perancangan sistem aplikasi yang ada telah didasari dari penelitian sebelumnya, yaitu sistem Bhuvanya, Vijayalakshmi, dan Uma, yang menggabungkan collaborative filtering dengan agglomerative hierarchical clustering untuk meningkatkan performa sistem dalam hal efisiensi waktu [4]. Sistem yang dirancang tersebut membantu dalam kompilasi data sehingga tingkatan prediksi akan lebih mudah dilakukan. Penelitian D'Addio, et. al. juga menunjukkan bahwa teknik text preprocessing yang dilakukan akan sangat berdampak pada hasil sistem rekomendasi, tergantung pada spesifikasi basis data yang diproses, dan pendekatan hierarchical sesuai untuk basis data yang besar [3].

Pada penelitian ini, gabungan clustering untuk membuat kompilasi data makanan dan filtering konten yang telah diproses terlebih dahulu dirancang untuk membuat sistem yang efeksi dan efisien dengan data dari basis data makanan FatSecret.

\section{METODOLOGI PENELITIAN}

\section{A. Kebutuhan Kalori Tubuh Manusia}

Kebutuhan kalori dalam tubuh manusia dapat diketahui melalui faktor-faktor dari Physical Activity Level (PAL), Basal Metabolic Rate (BMR), dan Total Energy Expenditure (TEE). PAL adalah sebuah standar pengukuran yang biasa digunakan untuk menghitung besarnya tingkat aktivitas fisik seseorang dalam waktu 24 jam [2]. Perhitungan nilai PAL yang diperoleh akan mempengaruhi kebutuhan nutrisi yang harus dikonsumsi seseorang. Tingkatan PAL diklasifikasikan berdasarkan gaya hidup yang dimiliki seperti yang ditampilkan pada tabel 1 di bawah ini.

Tabel 1. Klasifikasi Gaya Hidup Sehubungan dengan PAL

\begin{tabular}{c|c}
\hline Kategori & Nilai PAL \\
\hline Sedentary or lightly active & $1,40-1,69$ \\
\hline Active or moderately active & $1,70-1,99$ \\
\hline Vigorously or vigorously active & $2,00-2,40$ \\
\hline
\end{tabular}

Dari Tabel 1 di atas, yang dimaksud dengan sedentary or lightly active adalah orang dengan kegiatan sehari-hari yang tidak menuntut aktivitas fisik banyak atau yang berolahraga sebanyak satu hingga tiga kali dalam satu minggu. Active or moderately active adalah orang dengan kegiatan sehari-hari yang memiliki tuntutan aktivitas fisik serupa berolahraga rutin sebanyak empat sampai lima kali dalam satu minggu. Vigorously or vigorously active adalah orang dengan kegiatan sehari-hari yang menuntut tingkat aktivitas fisik seperti altlet atau yang berolahraga rutin setiap hari [2].

BMR adalah tingkat minimal dari kebutuhan energi yang dibutuhkan untuk menjaga fungsi tubuh atau melakukan aktivitas dasar tubuh, yang dapat diperhitungkan melalui persamaan (1) dan (2) di bawah ini.

$$
\begin{aligned}
& \operatorname{BMR}(\text { male })=(10 \times \text { weight })+(6.25 \times \text { height })-(5 \times \text { age })+5 \\
& \operatorname{BMR}(\text { female })=(10 \times \text { weight })+(6.25 \times \text { height })- \\
&(5 \times \text { age })-161
\end{aligned}
$$

Dari persamaan (1) dan (2) di atas, weight yang dimaksud adalah berat badan dan diukur dalam satuan kilogram, height adalah tinggi badan dan diukur dalam satuan sentimeter, dan age adalah usia yang diukur dengan tahun [5].

TEE adalah rata-rata dari keseluruhan energi yang dikeluarkan dalam waktu dua puluh empat jam [2]. Untuk menghitung perbedaan dari tingkat aktivitas fisik di antara gaya hidup yang beragam, nilai TEE diestimasi berdasarkan perhitungan faktorial yang mempertimbangkan waktu dan banyaknya energi yang dikeluarkan pada aktivitas sehari-hari, seperti yang ditampilkan pada tabel 2 , untuk mengetahui PAL. 
Tabel 2. Perhitungan Faktorial dari TEE untuk Kelompok Populasi

\begin{tabular}{l|c|c|c}
\hline \multicolumn{1}{c|}{ Aktivitas } & $\begin{array}{c}\text { Alokasi } \\
\text { Waktu } \\
\text { (Jam) }\end{array}$ & $\begin{array}{c}\text { Biaya } \\
\text { Waktu x } \\
\text { Energi }\end{array}$ & $\begin{array}{c}\text { Mean PAL } \\
\text { (Kelipatan } \\
\text { BMR 24 Jam) }\end{array}$ \\
\hline $\begin{array}{l}\text { Sedentary or } \\
\text { lightly active }\end{array}$ & 24 & 36,7 & $36,7 / 24=1,53$ \\
\hline $\begin{array}{l}\text { Active or } \\
\text { moderately } \\
\text { active }\end{array}$ & 24 & 42,2 & $42,2 / 24=1,76$ \\
\hline $\begin{array}{l}\text { Vigorously or } \\
\text { vigorously } \\
\text { active }\end{array}$ & 24 & 53,9 & $53,9 / 24=2,25$ \\
\hline
\end{tabular}

Perhitungan atas kebutuhan energi didapatkan dari estimasi faktorial mean PAL dan mengalikannya dengan BMR, seperti persamaan (3) di bawah ini.

$T E E=$ Mean $P A L \times B M R$

B. Sistem Rekomendasi Berbasis Konten

Sistem rekomendasi akan dibuat berdasarkan data yang didapatkan dari data pengguna. Content-Based Filtering (CBF) merupakan algoritma rekomendasi yang menghitung setiap weight dari item yang ada untuk dibandingkan dan mencari tingkat kesamaaan yang tinggi untuk membuat rekomendasi [6]. Item biasanya diwakili oleh model konten yang mengandung fitur dari item tersebut. Fitur yang dimaksud umumnya berbasis kata, seperti suatu kata spesifik, frasa, dan n-gram.

Salah satu cara menghitung kesamaan dengan cosine similarity, yaitu pengukuran kesamaan untuk membandingkan dokumen atau peringkat dokumen dengan dasar vektor dari kata query yang dicari. Contohnya $\mathrm{x}$ dan $\mathrm{y}$ sebagai vektor komparasi dengan penerapan perhitungannya sebagai berikut:

$\operatorname{sim}(x, y)=\frac{x \cdot y}{\|x\||| y \|}$

Dari persamaan (4) di atas, $\|\mathrm{x}\|$ adalah Euclidean norm dari vektor $\quad \mathrm{x}=\left(\mathrm{x}_{1}, \quad \mathrm{x}_{2}, \ldots, \quad \mathrm{x}_{\mathrm{p}}\right), \quad$ didefinisikan sebagai $\sqrt{ }\left(\mathrm{x}_{1}{ }^{2}+\mathrm{x}_{2}{ }^{2}+\ldots+\mathrm{x}_{\mathrm{p}}{ }^{2}\right)$, sebagai panjang vektor. Sedangkan $\|\mathrm{y}\|$, serupa dengan $\mathrm{x}$, adalah Euclidean norm dari vektor $\mathrm{y}$. Perhitungan ini mengukur sudut kosinus antara vektor $\mathrm{x}$ dan y. Nilai kosinus nol menyatakan kedua vektor berada sembilan puluh derajat satu sama lain (orthogonal) dan tidak memiliki kesamaan. Semakin dekat nilai ke kosinus satu, semakin kecil sudut dan semakin besar nilai kesamaan antar vektor [6].

\section{Hierarchical Clustering}

Pada penelitian ini, clustering dilakukan dengan pendekatan agglomerative hierarchical clustering, yaitu salah satu cara untuk mengelompokkan objek data pada tingkatan yang berbeda melalui cluster dengan strategi bawah-atas [7]. Setiap objek yang ada dimasukkan pada cluster sendiri dan pada setiap iterasi, objek tersebut bergabung dengan objek lain hingga terbentuk satu cluster atau menjumpai kondisi tertentu.

Dalam penerapannya, penentuan jarak antar cluster akan menggunakan perhitungan jarak average distance, yang dapat dilihat pada persamaan (5) di bawah ini.

$\operatorname{dist}_{\text {avg }}\left(C_{i}, C_{j}\right)=\frac{1}{n_{i} n_{j}} \sum_{p \epsilon C_{i}, p^{\prime} \epsilon C_{j}}\left|p-p^{\prime}\right|$

Dari persamaan (5) di atas, $\left|p-p^{\prime}\right|$ adalah jarak antara dua objek atau titik $\mathrm{p}$ dan $\mathrm{p}^{\prime}$; dan ni dan nj adalah jumlah objek $\mathrm{Ci}$ dan $\mathrm{Cj}$.

Pada hierarchical clustering, pengelompokan objek yang ada biasa digambarkan dengan sebuah dendrogram, yaitu diagram dengan struktur pohon yang merepresentasikan hasil proses dari clustering tersebut.

\section{Skala Likert dengan Analisis Interval}

Skala Likert merupakan skala penelitian yang digunakan untuk mengukur sikap atau persepsi seseorang terhadap serangkaian pernyataan, biasanya skala ini termasuk dalam skala rating karena didasari konsep pengukuran sikap yang sama [8]. Dalam skala ini, setiap item yang ada adalah sebuah pernyataan deklaratif, dan akan ditanggapi dengan lima opsi jawaban. Untuk menganalisis hasil dengan analisis interval, opsi jawaban skala Likert diberi nilai Sangat Tidak Sejutu memiliki nilai 1, Tidak Setuju memiliki nilai 2, Netral memiliki nilai 3, Setuju memiliki nilai 4, dan Sangat Setuju memiliki nilai 5. Setelah itu, menghitung total dari nilai item Likert, yang didapat dengan mengkalikan jawaban responden dengan nilai jawaban yang ada.

Kesimpulan dari setiap item diketahui dari persentase hasil indeks interval penilaian di mana total nilai item dibagi dengan nilai maksimum dan dikali serratus. Berikut ini kesimpulan interval penilaian suatu item:

1) Indeks $0 \%-20 \%$ berarti responden sangat tidak setuju dengan pernyataan yang ada.

2) Indeks $21 \%$ - $40 \%$ berarti responden tidak setuju dengan pernyataan yang ada.

3) Indeks $41 \%$ - $60 \%$ berarti responden netral dengan pernyataan yang ada.

4) Indeks $61 \%$ - $80 \%$ berarti responden setuju dengan pernyataan yang ada.

5) Indeks $81 \%$ - $100 \%$ berarti responden sangat setuju dengan pernyataan yang ada.

E. Analisis Kebutuhan Rekomendasi

Analisis ini dilaksanakan untuk mendapatkan kebutuhan rekomendasi pada sistem, khususnya mengenai kebutuhan kalori manusia dan makanan alternatif yang sesuai. Metode pelaksanaan ini adalah wawancara terhadap tiga orang nutritionist yang memiliki kualifikasi pekerjaan dalam bidang penilitian gizi dengan minimal gelar sarjana yang fokus pada kesehatan dan gizi.

Wawancara dijalankan dengan aspek pertanyaan sebagai berikut: 
1) Mengetahui kebutuhan kalori tubuh manusia, untuk memastikan perhitungan kebutuhan kalori yang sesuai untuk tubuh manusia.

2) Mengetahui kemungkinan adanya makanan alternatif lebih sehat yang didapatkan dari bahan makanan serupa, untuk memastikan rekomendasi hasil makanan alternatif cukup didapat dari kalori dan bahan makanan saja.

Kesimpulan hasil wawancara yang didapat untuk pertanyaan tersebut sebagai berikut:

1) Untuk pertanyaan pertama, ketiga nutritionist setuju bahwa persamaan yang digunakan sudah cukup sesuai untuk menghitung estimasi kebutuhan kalori yang dibutuhkan tubuh manusia. Penelitian ini fokus terhadap orang dengan tingkat aktivitas minim dan tidak memiliki kebutuhan khusus atau mengidap penyakit apapun sehingga persamaan sudah mencantumkan faktor yang sesuai untuk perhitungan kalori.

2) Untuk pertanyaan kedua, dua dari ketiga nutritionist setuju bahwa hasil rekomendasi makanan alternatif cukup didapat melalui kalori dan bahan makanan serupa saja. Satu nutritionist yang tidak setuju dikarenakan jika makanan dinilai lebih sehat maka harus dipertimbangkan juga kandungan nutrisi makro dan mikro.

\section{F. Analisis Kebutuhan Aplikasi}

Analisis ini dilaksanakan melalui komparasi tiga aplikasi sejenis untuk mendapatkan kebutuhan aplikasi yang dirancang. Aplikasi yang dipilih untuk komparasi merupakan aplikasi dengan fungsi perhitungan kalori, memiliki rating di Google Play Store minimal 4,5, dan merupakan aplikasi yang banyak dipakai orang berdasarkan jumlah unduhan sepuluh juta lebih. Aplikasi yang dipilih adalah aplikasi Calorie Counter by FatSecret, Calorie Counter - MyFitnessPal, dan Calorie Counter, Home Workout \& Immunity Plan (HealthifyMe).

Aspek komparasi yang dilakukan fokus pada dua fitur yang juga diterapkan pada aplikasi yang dirancang, yaitu: 1) pengambilan informasi pengguna, yang ada sebagai fitur aplikasi untuk menghitung kebutuhan kalori pengguna, dan 2) tampilan pencarian makanan, yang ada sebagai fitur utama aplikasi untuk memberi masukkan pilihan makanan yang akan diberi rekomendasi.

Dari hasil komparasi yang didapat, pengambilan informasi pengguna difokuskan untuk perhitungan TEE sehingga mengambil informasi jenis kelamin, berat badan, tinggi badan, dan tanggal lahir pengguna. Informasi tersebut dipilih karena fungsi aplikasi yang sudah dikhususkan untuk pemberian rekomendasi kepada pengguna dengan tingkat aktivitas minim dan fungsi aplikasi tidak mengacu untuk membantu penurunan berat badan pengguna.

Untuk pencarian makanan, sesuai hasil komparasi, informasi yang ditampilkan pada pencarian adalah nama makanan, deskripsi makanan sebagai pengganti porsi karena dalam penelitian makanan yang diambil merupakan makanan dengan data bahan makanan, dan kalori makanan.
G. Desain Sistem Rekomendasi Berbasis Konten dengan Hierarchical Clustering

Dalam sistem rekomendasi ini, ada tiga sisi berhubungan, yaitu Python yang melaksanakan perhitungan dan pembuatan rekomendasi, Android yang mencari dan mengambil data makanan dari FatSecret API serta mengirim dan mengambil data makanan, dan PHP yang menangani pelemparan dan pengambilan data ke basis data di localhost.

Proses-proses tersebut memiliki tahap sebagai berikut:

1) Proses hierarchical clustering dan content-based filtering di Python. 2.

Jalan sistem yang ada digambarkan pada melalui Gambar

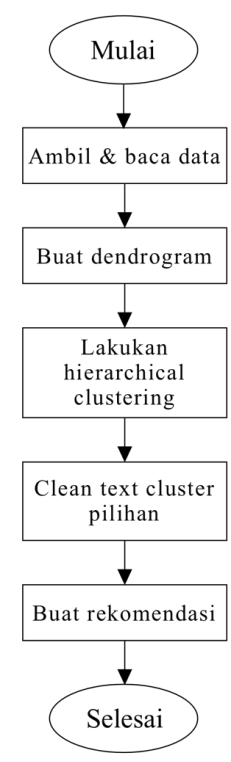

Gambar 2. Jalan Proses Clustering dan Filtering di Python

Jalannya sistem diawali dengan proses pengambilan dan pembacaan data dari basis data makanan di localhost. Setelah data makanan didapatkan, nilai dari data makanan yang diambil untuk dibuat cluster adalah data bahan makanan, kalori makanan, dan berat makanan, yang merupakan nilai numeric. Dendrogram disusun melalui library scipy dengan parameter nilai data yang diambil dan metode average linkage, untuk membantu dalam penentuan jumlah cluster untuk parameter hierarchical clustering. Hasil dendrogram akan menunjukan penggambaran awal hierarchical clustering dan dari data tersebut ditentukan terbentuk empat cluster.

Hierarchical clustering dilaksanakan oleh function Agglomerative Clustering dari library sklearn untuk dapat membentuk kelompok data sesuai dari data makanan yang ada. Nilai pengelompokan (cluster labels) yang didapat dari hasil clustering akan dimasukkan dalam kolom cluster yang ditampung pada DataFrame baru untuk kemudahan pencarian kelompok yang sesuai dengan masukkan data makanan pengguna.

Selanjutnya, cluster yang mengandung pilihan makanan pengguna diambil untuk persiapan content-based filtering. Sebelum dilakukang filtering, proses clean text dilakukan 
untuk menghilangkan stopwords yang ada agar memudahkan pengukuran tingkat kesamaan antar kata. Data yang telah diproses lalu dimasukkan ke dalam kolom baru dengan nama desc_clean. Untuk dapat dicari tingkat kesamaan antar makanan, data desc_clean diterapkan perhitungan dengan TFIDF (Term Frequency-Inverse Document Frequency) yang merupakan metode library sklearn untuk menghitung bobot setiap kata dalam dokumen dan cosine similarity untuk mendapatkan relevansi terdekat.

Rekomendasi dibuat dengan mengambil hasil dari processing data similarity oleh TF-IDF dan cosine similarity lalu memasukkan variabel ID dari makanan pilihan pengguna sebagai input untuk menilai kesamaan. Setelah data rekomendasi didapatkan, data tersebut dimasukkan ke dalam DataFrame baru yang hanya mengandung satu kolom berisi ID dari makanan hasil rekomendasi, dan disimpan ke basis data di localhost.

2) Proses FatSecret API serta pelemparan data di Android.

Dalam Android, dilakukan penerapan FatSecret API untuk pencarian dan pengambilan data makanan dari server FatSecret serta adanya pelemparan data makanan yang didapatkan ke server localhost.

\section{3) Proses sisi PHP}

Proses ini membantu Android dalam membangun koneksi server localhost untuk melakukan pengiriman dan pengambilan data pada Android.

\section{H. Desain Arsitektur}

Pada aplikasi ini, Android adalah sisi klien yang akan menjadi perantara pengguna dengan aplikasi itu sendiri dalam koneksi ke sisi server, yaitu FatSecret API untuk pemanggilan basis data makanan, server localhost (Food) yang menyimpan basis data makanan dan makanan pengguna, serta Python yang menjalankan algoritma rekomendasi. Android memberikan query kepada FatSecret API untuk memanggil basis data makanan yang ada dan ditampilkan dalam aplikasi. Data makanan tersebut dan data makanan yang dipilih oleh pengguna akan dikirim ke localhost dengan bantuan PHP kemudian diteruskan ke Python untuk dilakukan clustering dan filtering. Server localhost ditujukan untuk menjadi tempat penampungan dalam pelemparan data yang diproses server ke klien. Desain yang telah dirancang dapat dilihat pada Gambar 3 di bawah ini.

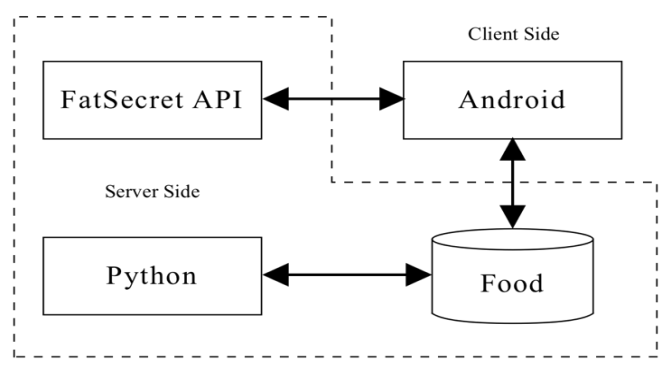

Gambar 3. Desain Arsitektur Aplikasi

\section{Use Case Diagram}

Aplikasi ini dirancang untuk satu pengguna dan data informasi pengguna hanya disimpan pada aplikasi sehingga tidak ada admin lain. Dalam aplikasi ini, pengguna dapat memasukkan data berupa informasi jenis kelamin, berat badan, tinggi badan, dan tanggal lahir, serta pengguna juga dapat mencari makanan yang diinginkan untuk mendapatkan rekomendasi makanan serupa. Hal tersebut disampaikan pada Gambar 4 di bawah ini.

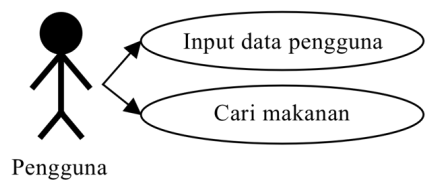

Gambar 4. Use Case Diagram Aplikasi

\section{J. Activity Diagram}

Untuk input data pengguna, dimulai dengan pengguna memasukkan data pengguna yang kemudian disimpan oleh Android. Data pengguna yang ada akan diperhitungkan dalam Android untuk menampilkan hasil kebutuhan kalori pengguna. Alur yang ada digambarkan pada Gambar 5 di bawah ini.

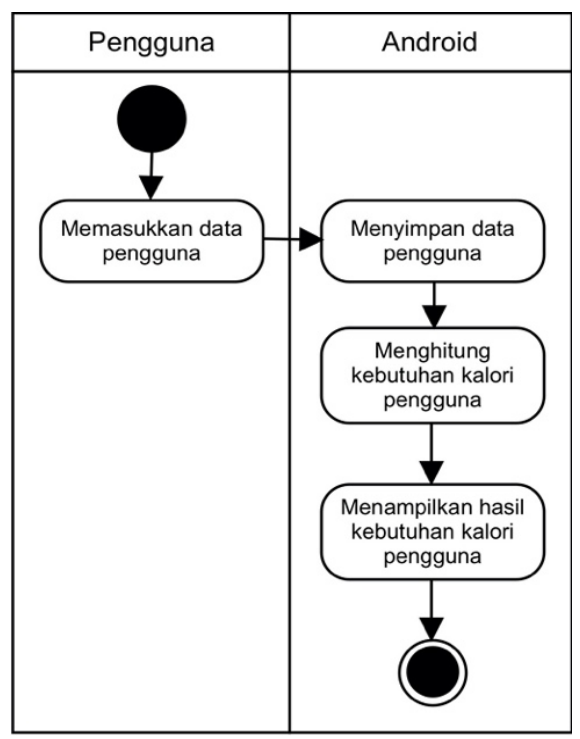

Gambar 5. Activity Diagram untuk Input Data Pengguna

Untuk pencarian makanan, pengguna mencari makanan yang sesuai dengan apa yang diinginkan. Dalam Android, aplikasi akan mengirim query ke FatSecret API untuk menampilkan data makanan yang dapat dipilih pengguna. Pengguna melakukan pemilihan makanan sebagai parameter rekomendasi makanan. Android akan mengirimkan data pengguna ke Food Database berupa server localhost untuk mengirimkan data tersebut ke Python agar dapat dilakukan clustering lalu filtering. Hasil yang diperoleh akan dikirim ke localhost untuk diteruskan ke Android agar pengguna dapat melihat data rekomendasi makanan yang tersusun. Alur yang ada digambarkan pada Gambar 6 di bawah ini. 


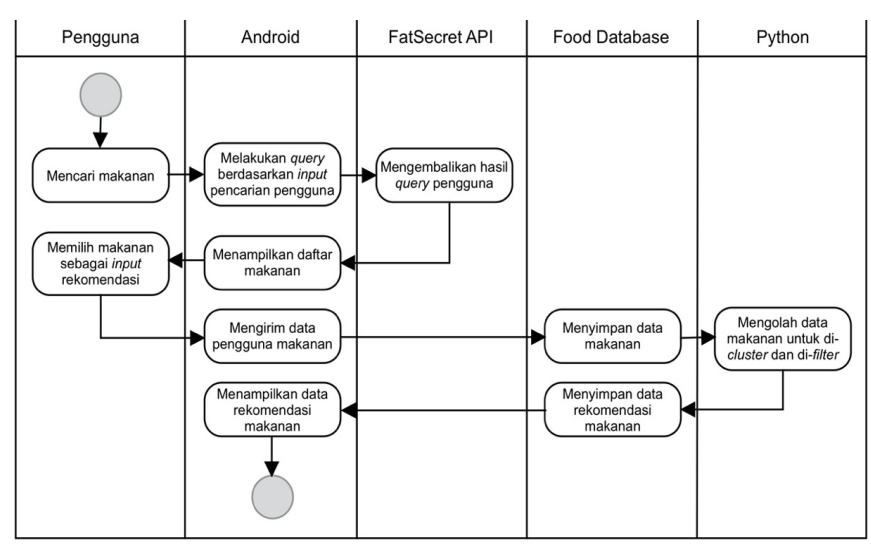

Gambar 6. Activity Diagram untuk Cari Makanan

\section{K. Basis Data Makanan}

Basis data makanan dengan nama food ditujukan untuk dapat menampung semua data makanan yang ada setelah diambil dari FatSecret. Data makanan ini akan menjadi dataset untuk sistem rekomendasi. Basis data food akan menyimpan data ID makanan (recipe_id) sebagai primary key, nama makanan (recipe_name), ID bahan makanan (food_id), nama bahan makanan (food_name), kalori makanan (calories), berat makanan (units), dan deskripsi berat makanan (measurement). Desain dari basis data makanan dapat dilihat pada Gambar 7.

food

\begin{tabular}{|l|l|l|l|l|l|l|}
\hline recipe id & recipe_name & food__d & food_name & calories & units & measurement \\
\hline
\end{tabular}

Gambar 7. Desain Basis Data Makanan

\section{Desain User Interface}

Untuk rancangan aplikasi ini, ada empat desain utama, yaitu desain halaman input user data, home, search, dan recommendation. Desain halaman input user data akan menggunakan desain serupa dengan aplikasi FatSecret untuk memudahkan tanggapan yang akan diberi pengguna yang fokus dengan pertanyaan untuk mendapatkan variabel perhitungan TEE (jenis kelamin, berat badan, tinggi badan, dan tanggal lahir). Pada halaman ini akan ada TextView untuk menampilkan pertanyaan, EditText sebagai kotak jawaban atau RadioButton sebagai pilihan jawaban untuk input pengguna, dan Button untuk menampilkan halaman selanjutnya. Gambar halaman input user ditampilkan pada Gambar 8.

Desain halaman home akan menampilkan jumlah kalori yang dibutuhkan pengguna berdasarkan perhitungan TEE serta memberi akses langsung untuk mengubah data pengguna dan mencari makanan untuk mendapatkan rekomendasi. Pada halaman ini, akan ditampilkan gambar jenis kelamin sebagai deskripsi utama data pengguna melalui ImageView, serta hasil TEE dan keterangan banyak kalori yang dapat dikonsumsi tiap makan melalui TextView. Dua fitur aplikasi juga dimunculkan dalam bentuk Button untuk memudahkan akses pengguna. Gambar desain halaman home ditampilkan pada Gambar 9.

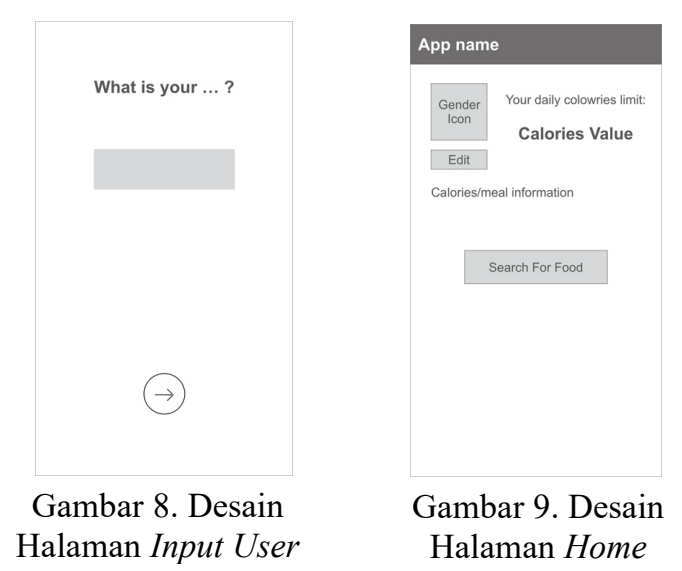

Desain halaman search fokus untuk menampilkan halaman pencarian makanan, dengan tampilan daftar hasil makanan yang mengandung nama makanan, deskripsi makanan, dan kalori makanan. Untuk memberi tampilan yang jelas, daftar makanan akan ditampilkan dengan ListView. Gambar desain halaman search ditampilkan pada Gambar 10.

Desain halaman recommendation fokus untuk menampilkan makanan pilihan yang dicari pengguna serta hasil rekomendasi berupa daftar makanan serupa. Pada halaman ini akan fokus pada rekomendasi sehingga akan ada TextView untuk menampilkan data makanan yang dipilih dan ListView untuk menampilkan hasil rekomendasi secara langsung. Button dengan nama recommendations berfungsi untuk menampilkan hasil rekomendasi ke ListView dan Button Go back to Home berfungsi untuk kembali ke halaman Home. Gambar halaman recommendation ditampilkan pada Gambar 11.

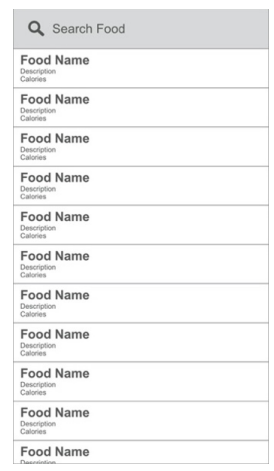

Gambar 10. Desain Halaman Search

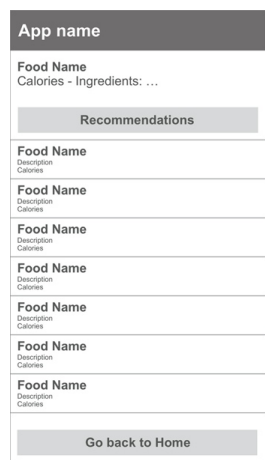

Gambar 11. Desain Halaman Recommendation

\section{HASIL DAN PEMBAHASAN}

\section{A. Implementasi User Interface}

Tampilan user interface dalam aplikasi akan dirancang sesuai dengan desain user interface yang telah jelaskan sebelumnya. Untuk halaman awal yang dijumpai pengguna adalah halaman-halaman input user data. Implementasi desain untuk halaman pertama yang dilihat pengguna dapat dilihat pada Gambar 12, yang menampilkan teks penyambutan dan tombol lanjut ke halaman input user data selanjutnya. Halaman ini memiliki desain yang sama dengan struktur 
halaman untuk user input data tetapi tidak ada kotak jawaban masukkan pengguna.

Halaman input user data kedua menampilkan halaman dengan pertanyaan jenis kelamin pengguna, opsi jawaban pengguna dengan gambar laki-laki dan perempuan, dan tombol lanjut. Implementasi desain halaman ini dapat dilihat pada Gambar 13.

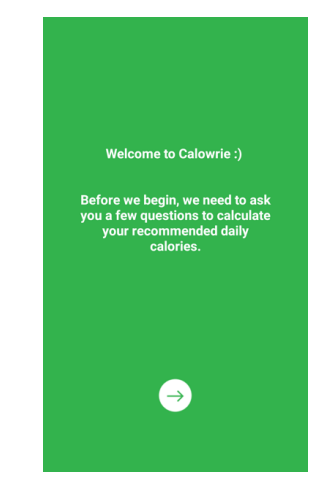

Gambar 12. Halaman Input User Data - Welcome
Gambar 16. Halaman Input User Data - Age

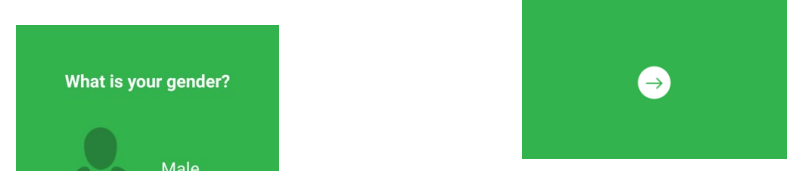

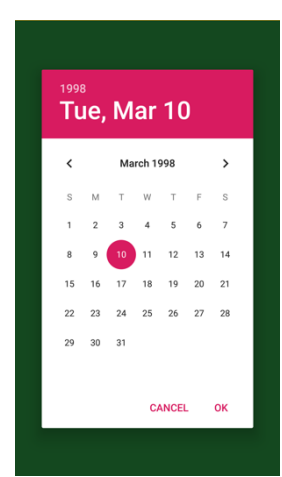

Gambar 17. Halaman PopUp Calendar
Setelah pengguna memasukkan semua data yang diperlukan, pengguna masuk pada halaman home. Pada halaman home, pengguna dapat melihat perhitungan kebutuhan kalori yang dibutuhkan setiap harinya dan keterangan akan konsumsi kalori yang baik setiap makan. Pada halaman ini juga terdapat dua tombol untuk mengarah kembali ke halaman user input data - gender dan mengarah ke halaman search. Implementasi desain halaman ini dapat dilihat pada Gambar 18.

Halaman search menampilkan baris pencarian di mana pengguna dapat memasukkan sebuah query untuk mencari data makanan FatSecret, daftar pencarian makanan, dan tombol kembali ke halaman home. Daftar yang muncul akan menampilkan nama makanan, kalori makanan, dan keterangan makanan. Implementasi desain halaman search dapat dilihat pada Gambar 19.

Halaman recommendation akan muncul jika pengguna menekan pada satu item makanan dari daftar makanan di halaman search. Pada halaman ini akan ditampilkan nama, kalori, dan bahan dari pilihan makanan yang dicari pengguna. Dalam halaman ini terdapat dua tombol, yaitu tombol dengan nama Recommendations untuk menampilkan daftar makanan alternatif berkalori lebih rendah dengan bahan serupa dan tombol dengan nama Go back to Home untuk mengarah balik ke halaman home. Implementasi desain halaman recommendation dapat dilihat pada Gambar 20.

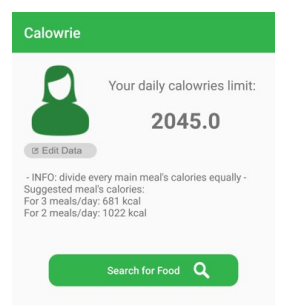

Gambar 18.

Halaman Home

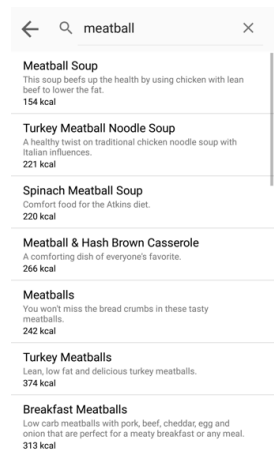

Gambar 19.

Halaman Search 


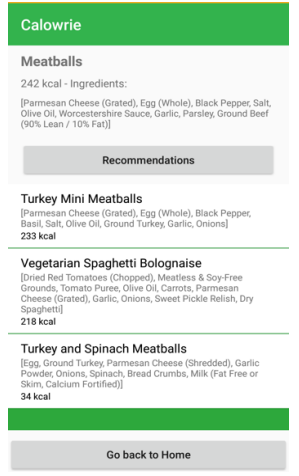

Gambar 20. Halaman Recommendation

\section{B. Pengujian}

Pengujian ini ditujukan untuk menilai tingkat kepuasan pengguna akan hasil rekomendasi makanan dengan rasa serupa yang didapat berdasarkan jumlah kalori makanan dan bahan makanan dengan hierarchical clustering dan content-based filtering melalui metode pengujian yang menggunakan analisis interval dari skala Likert.

Responden dalam pengujian ini adalah responden dengan usia 18 - 64 tahun, memiliki tingkat aktivitas yang minim, dan peduli akan jumlah kalori yang dikonsumsi oleh tubuh. Untuk mendapatkan responden dengan kriteria tersebut maka dilakukan seleksi data responden yang sesuai berdasarkan jawaban responden saat pengujian.

Berikut ini adalah aspek pertanyaan yang ditujukan dalam pengujian:

1) Usia Anda?

2) Tingkat aktivitas sehari-hari Anda?

3) Apakah Anda peduli akan konsumsi kalori Anda?

4) Apakah makanan yang telah direkomendasi memiliki rasa serupa dengan makanan yang diajukan?

Pertanyaan satu, dua, dan tiga di atas akan menunjukan kriteria responden sehingga dapat dilakukan seleksi terhadap responden yang sesuai. Pertanyaan empat akan menunjukan tingkat kepuasan responden atas rasa makanan serupa yang menjadi dasar keberhasilan pengujian aplikasi. Pada pertanyaan empat, responden akan menentukan jawaban mereka yang ditampilkan pada skala Likert untuk perbandingan makanan sebagai berikut:

1. Makanan yang diajukan: Pizza Wrap $-238 \mathrm{kcal}$

Makanan hasil rekomendasi:
a. Ham and Cheese Frittata - $112 \mathrm{kcal}$
b. Ham Wrap $-178 \mathrm{kcal}$
c. Pizza Muffins - $159 \mathrm{kcal}$

2. Makanan yang diajukan: Beef Burgers - $292 \mathrm{kcal}$

Makanan hasil rekomendasi:
a. Meatballs - $242 \mathrm{kcal}$
b. Chicken Burgers - $164 \mathrm{kcal}$
c. Turkey Mini Meatballs - $233 \mathrm{kcal}$

3. Makanan yang diajukan: Chicken Katsu $-454 \mathrm{kcal}$ Makanan hasil rekomendasi:
a. Chicken Burgers - $164 \mathrm{kcal}$
b. Chicken Pillows - $193 \mathrm{kcal}$
c. Teriyaki Chicken $-330 \mathrm{kcal}$

4. Makanan yang diajukan: Chocolate Pudding - $428 \mathrm{kcal}$
Makanan hasil rekomendasi:
a. Dark Chocolate Pudding - $123 \mathrm{kcal}$
b. Chocolate Treasure $-40 \mathrm{kcal}$
c. Peanut Butter \& Chocolate Pudding - $347 \mathrm{kcal}$

5. Makanan yang diajukan: Spaghetti Carbonara $-422 \mathrm{kcal}$ Makanan hasil rekomendasi:
a. Tofu Fried Rice - $301 \mathrm{kcal}$
b. Egg Crepes - $291 \mathrm{kcal}$
c. Vegetarian Spaghetti-325 kcal

6. Makanan yang diajukan: Pepperoni Pizza-398 kcal Makanan hasil rekomendasi:
a. Ham \& Pepperoni Pizza - $321 \mathrm{kcal}$
b. Meatball \& Hash Brown Casserole - $266 \mathrm{kcal}$
c. Chicken Spaghetti-318 kcal

7. Makanan yang diajukan: Chicken Soup - 154 kcal

Makanan hasil rekomendasi:
a. Hamburg Soup - $142 \mathrm{kcal}$
b. Tomato Soup - $55 \mathrm{kcal}$
c. Greek Salad - $139 \mathrm{kcal}$

8. Makanan yang diajukan: Chunky Potato French Fries $118 \mathrm{kcal}$

Makanan hasil rekomendasi:
a. Roasted Sweet Potato Wedges - $66 \mathrm{kcal}$
b. French Crepes - $84 \mathrm{kcal}$
c. Sweet Potato Apple Cake - $91 \mathrm{kcal}$

9. Makanan yang diajukan: French Toast $-354 \mathrm{kcal}$ Makanan hasil rekomendasi:

a. Cinnamon Toast $-118 \mathrm{kcal}$

b. Fruit Sandwich $-266 \mathrm{kcal}$

c. French Toast Crepes $-341 \mathrm{kcal}$

10. Makanan yang diajukan: Meatballs $-242 \mathrm{kcal}$

Makanan hasil rekomendasi:
a. Turkey Mini Meatballs - $233 \mathrm{kcal}$
b. Vegetarian Spaghetti Bolognaise - $218 \mathrm{kcal}$
c. Turkey and Spinach Meatballs - $34 \mathrm{kcal}$

Skenario pengujian yang dijalankan dalam penelitian ini adalah menggunakan aplikasi yang telah dirancang untuk mendapatkan rekomendasi atas sepuluh makanan, dengan setiap makanan memberikan tiga makanan hasil rekomendasi. Hasil rekomendasi tersebut dituliskan dalam survei melalui Google Form yang kemudian disebarkan secara luas untuk mendapatkan responden.

Dari hasil survei yang telah disebarkan, terdapat 32 dari 40 responden yang telah memenuhi kriteria yang dituju sehingga data tersebut diseleksi untuk dilakukan pengujian tingkat kepuasan. Hasil yang didapatkan telah didata dalam Tabel 3 di bawah ini.

Tabel 3. Hasil Pengujian oleh 32 Responden

\begin{tabular}{c|c|c|c|c|c|c|c}
\hline $\begin{array}{c}\text { Maka } \\
\text { nan }\end{array}$ & $\begin{array}{c}\text { Rekomen } \\
\text { dasi }\end{array}$ & STM & TM & C & M & SM & $\begin{array}{c}\text { Indeks } \\
\text { Penilaian }\end{array}$ \\
\hline \multirow{3}{*}{1} & 1 & 2 & 5 & 10 & 6 & 9 & $69,4 \%$ \\
\cline { 2 - 8 } & 2 & 0 & 0 & 8 & 18 & 6 & $78,8 \%$ \\
\cline { 2 - 8 } & 3 & 2 & 4 & 8 & 14 & 4 & $68,8 \%$ \\
\hline \multirow{3}{*}{2} & 1 & 2 & 8 & 7 & 14 & 1 & $62,5 \%$ \\
\cline { 2 - 8 } & 2 & 0 & 3 & 6 & 12 & 11 & $79,4 \%$ \\
\hline \multirow{3}{*}{3} & 3 & 3 & 5 & 9 & 14 & 1 & $63,1 \%$ \\
\cline { 2 - 8 } & 1 & 6 & 5 & 12 & 7 & 2 & $56,3 \%$ \\
\hline 4 & 2 & 2 & 1 & 12 & 16 & 1 & $68,1 \%$ \\
\hline \multirow{2}{*}{4} & 1 & 1 & 2 & 8 & 16 & 5 & $73,8 \%$ \\
\hline
\end{tabular}




\begin{tabular}{|c|c|c|c|c|c|c|c|}
\hline & 2 & 0 & 3 & 11 & 11 & 7 & $73,8 \%$ \\
\hline & 3 & 1 & 3 & 3 & 15 & 10 & $78,8 \%$ \\
\hline \multirow{3}{*}{5} & 1 & 6 & 17 & 7 & 2 & 0 & $43,1 \%$ \\
\hline & 2 & 5 & 17 & 7 & 3 & 0 & $45 \%$ \\
\hline & 3 & 0 & 5 & 11 & 13 & 3 & $68,8 \%$ \\
\hline \multirow{3}{*}{6} & 1 & 0 & 0 & 3 & 9 & 20 & $90,6 \%$ \\
\hline & 2 & 2 & 6 & 16 & 7 & 1 & $59,4 \%$ \\
\hline & 3 & 2 & 6 & 12 & 9 & 3 & $63,1 \%$ \\
\hline \multirow{3}{*}{7} & 1 & 0 & 2 & 3 & 12 & 15 & $85 \%$ \\
\hline & 2 & 0 & 5 & 12 & 5 & 10 & $72,5 \%$ \\
\hline & 3 & 4 & 9 & 11 & 6 & 2 & $55,6 \%$ \\
\hline \multirow{3}{*}{8} & 1 & 0 & 0 & 2 & 10 & 20 & $91,3 \%$ \\
\hline & 2 & 1 & 11 & 9 & 6 & 5 & $61,9 \%$ \\
\hline & 3 & 0 & 7 & 8 & 8 & 9 & $71,9 \%$ \\
\hline \multirow{3}{*}{9} & 1 & 0 & 1 & 7 & 11 & 13 & $82,5 \%$ \\
\hline & 2 & 3 & 8 & 13 & 5 & 3 & $58,1 \%$ \\
\hline & 3 & 0 & 0 & 3 & 14 & 15 & $87,5 \%$ \\
\hline \multirow{3}{*}{10} & 1 & 0 & 1 & 1 & 12 & 18 & $89,4 \%$ \\
\hline & 2 & 2 & 8 & 10 & 8 & 4 & $62,5 \%$ \\
\hline & 3 & 1 & 0 & 2 & 14 & 15 & $86,3 \%$ \\
\hline
\end{tabular}

Keterangan: M. Ajuan merupakan makanan yang diajuan dan STM, TM, C, M, dan SM merupakan opsi skala Likert.

Dari total rekomendasi 30 makanan oleh 32 responden, telah didapatkan nilai total sebanyak $3422 / 4800$ sehingga memiliki indeks penilaian sebesar $71,3 \%$ yang mengindikasikan bahwa responden memberi nilai memuaskan terhadap hasil rekomendasi yang didapat. Dapat ditemukan juga bahwa ada lima data makanan yang memiliki selisih lebih dari $20 \%$ pada penilain kepuasan dalam urutan rekomendasi. Untuk pemberian urutan rekomendasi, lima dari sepuluh makanan yang ada telah menempatkan makanan pertama sebagai pilihan pertama dengan dua makanan menempatkan makanan kedua dan tiga makanan menempatkan makanan ketiga.

Lima makanan yang memberikan pilihan makanan kedua dan ketiga sebagai pilihan pertama adalah pizza wrap, beef burgers, chicken katsu, spaghetti carbonara, dan French toast. Pada penilaian pizza wrap dan beef burgers, selisih antara penilaian rekomendasi makanan yang didapat kurang dari $20 \%$ sehingga rasa serupa masih didapatkan hanya saja pilihan rekomendasi memberikan makanan yang memiliki bentuk berbeda jika dilihat dari hasil rekomendasi tersebut.

Hasil penilaian makanan dengan rekomendasi urutuan makanan kedua dan ketiga sebagai makanan pertama mengindikasikan bahwa selisih yang ada dapat dikatakan tertera pada faktor rekomendasi bentuk, kategori, dan bahan utama makanan. Lima makanan yang pertama yang dipilih pengguna sebagai makanan serupa mengandung faktor-faktor tersebut selain faktor bahan serupa.

\section{KESIMPULAN}

Berdasarkan hasil dan pembahasan yang telah dilakukan, dapat disimpulkan bahwa sistem rekomendasi yang telah dirancang berhasil dalam memberikan rekomendasi makanan dengan bahan serupa dan kalori lebih rendah berdasarkan tingkat penilaian responden atas 30 makanan hasil rekomendasi yang memuaskan dengan indeks penilaian sebesar $71,3 \%$. Akan tetapi, urutan makanan rekomendasi kurang sesuai dengan nilai kepuasan responden dan banyak makanan memiliki selisih penilaian diatas 20\% sehingga hal tersebut mengindikasikan bahwa untuk mendapatkan rasa serupa, faktor bentuk, kategori dan bahan utama makanan sangat penting untuk dapat menaikan nilai akurasi sistem rekomendasi yang ada.

Aplikasi sistem rekomendasi ini dapat ditingkatkan lanjut dengan menambah jumlah dan detail makanan pada basis data makanan agar dapat menghitung bahan serupa dengan lebih akurat, serta adanya penambahan makanan lokal untuk memudahkan pengenalan rasa makanan bagi responden saat pengujian. Untuk meningkatkan akurasi dalam pemberian rekomendasi makanan dengan rasa serupa, penambahan variabel atas faktor bentuk, kategori, dan bahan utama makanan juga perlu dispesifikasikan.

\section{REFERENSI}

[1] Zobel, E.H., et al. (2016). Global Changes in Food Supply and the Obesity Epidemic. Current Obesity Reports, Vol. 5, pp. 449-455. DOI: 10.1007/s13679-0160233-8.

[2] World Health Organization, Food and Agriculture Organization of the United Nations, United Nations University. (2004). Human Energy Requirements. Diambil dari https://www.who.int/nutrition/publications/ nutrientrequirements/9251052123/en/

[3] D'Addio, et al. (2017). Exploiting Feature Extraction Techniques on Users' Reviews for Movies Recommendation. Journal of Brazilian Computer Society, 23(7). DOI:10.1186/s13173-017-0057-8.

[4] Bhuvanya, R., Vijayalakshmi, K., \& Uma, S. (2018). Movie Recommender System Using Two Way Filtering and Agglomerative Hierarchical Clustering. Journal of Computational and Theoretical Nanoscience, Vol. 15(6), pp. 2269-2272. https://doi.org/10.1166/jctn.2018.7450.

[5] Rickard, F. A., et al. (2019). Comparison of Measured and Estimated Resting Energy Expenditure in Adolescents and Young Adults With Severe Obesity Before and 1 Year After Sleeve Gastrectomy. Frontiers in Pediatrics, Vol. 7, 37. DOI:10.3389/fped.2019.00037.

[6] Beel, J., et al. (2015). Research-Paper Recommender Systems: A Literature Survey. International Journal on Digital Libraries, Vol. 17(4), pp. 305-338. DOI:10.1007/s00799-015-0156-0.

[7] Batule, R.M., \& Itkar, S.A. (2016). A Survey Paper on Different Clustering Techniques for Collaborative Filtering for Services Recommendation. International Journal of Computer Science and Information Technologies, Vol. 7 (3), pp. 1410-1413.

[8] Harpe, S.E.(2015). How to Analyze Likert and Other Rating Scale Data. Currents in Pharmacy Teaching and Learning, Vol. 7(6), pp. 836-850. https://doi.org/ 10.1016/j.cptl.2015.08.001 